Jurnal Agrohita Volume 2 Nomor 2 Tahun $2018 \mid \mathbf{2 0}$

\title{
PENGARUH BEBERAPA JENIS BAHAN ORGANIK TERHADAP PERTUMBUHAN VEGETATIF TANAMAN PADI (Oryza sativa L) METODE SRI (the System of Rice Intensification)
}

\author{
Yusnita Wahyuni Silitonga ${ }^{1}$, M. Nizar Hanafiah Nasution ${ }^{2}$ \\ ${ }^{1}$ Email: yusnita.wahyuni@um-tapsel.ac.id \\ ${ }^{2}$ Email: nizarhanafiah.12@gmail.com \\ ${ }^{1}$ Staf Pengajar Fakultas Pertanian Universitas Muhammadiyah Tapanui Selatan Jl Raja Inal \\ Siregar - Tanggal No 32, Padangsidimpuan 22716 \\ ${ }^{2}$ Staf Pengajar Program Studi Agroteknologi Universitas Graha Nusantara, Padangsidimpuan, \\ Sumatera Utara
}

\begin{abstract}
ABSTRAK
Penelitian tentang pengaruh beberapa jenis bahan organik terhadap pertumbuhan vegetatif tanaman padi (Oryza sativa L) metode SRI (the System of Rice Intensification) telah dilaksanakan di Sungai Bangek, Kelurahan Balai Gadang, Padang. Tujuan penelitian ini adalah untuk mengetahui jenis bahan organik yang berpengaruh lebih baik terhadap pertumbuhan vegetatif tanaman padi metode SRI. Penelitian ini disusun berdasarkan Rancangan Acak Lengkap yang terdiri dari 4 perlakuan dan 3 ulangan. Perlakuan tersebut terdiri dari : sampah kota, kotoran ayam, thitonia dan jerami padi. Dosis masing-masingnya adalah 5 ton/ha. Data penelitian, dianalisis secara statistik dengan uji $\mathrm{F}$ dan $\mathrm{F}$ hitung yang lebih besar dari nilai $\mathrm{F}$ tabel $5 \%$ maka dilanjutkan dengan Duncan's Multiple Range Test (DNMRT) pada taraf nyata 5\%. Berdasarkan hasil penelitian disimpulkan jenis bahan organik sampah kota, kotoran ayam, thitonia dan jerami padi memberikan pengaruh yang sama terhadap pertumbuhan vegetatif tanaman padi dengan metode SRI, kecuali jumlah anakan minggu ke 8 setelah tanam. Pengaruh yang paling baik terhadap jumlah anakan pada minggu ke 8 adalah thitonia dibandingkan dengan sampah kota, kotoran ayam dan jerami padi.
\end{abstract}

Kata kunci: Dosis, jerami, thitonia, kotoran ayam

\begin{abstract}
The research about the influences of several types of organic material toward the growth vegetative of rice (Oriza sativa L) with the System of Rice Intensification had already done in Sungai Bangek, Balai Gadang Sub-district, Padang. The aim of the research is to know the type of organic material which gives better influences on the growth vegetative of rice with SRI methods. The research uses complete randomized design (CRD) which consist of four treatments by three times repetitions. The treatments consist of organic city garbage, fowl sewage, thitonia, and straw. The dosage for each is five ton/ha. The data were analyzed statistically by using test $\mathrm{F}$ and $\mathrm{F}$ calculate is bigger than F table 5\% therefore it is continued by Duncan's New Multiple Test at 5\% degree of fraden. It can be conclude that from the result of the research the type of organic material influences on growth vegetative of rice with SRI methods, except the total of tillering on the eighth
\end{abstract}


week. The best influence on the total on the eight week is thitonia.The highest number of tillering on the $8^{\text {th }}$ week old rice resulted from the thitonia treatments.

\section{PENDAHULUAN}

Kita mengenal adanya ekstensifikasi dan intensifikasi dalam peningkatan produksi. Cara peningkatan produksi dengan intensifikasi antara lain dengan penggunaan varietas unggul, pemberian pupuk dengan takaran yang tepat dan pengairan yang cukup. Salah satu cara peningkatan produksi dengan intensifikasi adalah dengan menerapkan metode baru. Penerapan teknologi yang populer saat ini adalah teknik budidaya metode SRI (the System of Rice Intensification). Menurut Barkelaar (2001), metode SRI minimal menghasilkan panen 2 kali lipat dibandingkan metode konvensional karena telah terbukti di Madagaskar di mana pada beberapa tanah tidak subur yang produksi normalnya 2 ton/ha dapat meningkat menjadi lebih dari 8 ton/ha bahkan ada yang mencapai 20 ton/ha.

SRI dikembangkan dengan menggunakan pupuk kimia untuk meningkatkan hasil panen pada tanah-tanah kritis/marginal di Madagaskar, tetapi saat subsidi pupuk dicabut pada akhir tahun 1980, petani disarankan untuk menggunakan bahan organik, dan ternyata hasilnya lebih tinggi dibandingkan dengan yang konvensional (Barkelaar, 2001).

Salah satu upaya untuk menigkatkan hasil pertanian adalah dengan menggunakan varietas unggul. Salah satu padi unggul adalah varietas IR 42, varietas ini berdasarkan deskripsinya termasuk tipe tegak. Keunggulan dari varietas padi ini adalah ketika memasuki panen padi tersebut tidak mudah rebah atau bahkan tidak mengalami rebah sehingga mengurangi resiko kelihangan hasil

varietas unggul saja belum cukup dalam upaya meningkatkan hasil padi, tetapi harus diimbangi pula dengan pemberian pupuk yang tepat baik sumber, jenis dosis dan waktu pemberiannya. Selain itu sumber pupuk sebagai sumber hara utama sangat bermanfaat bagi peningkatan produksi pertanian baik kualitas maupun kuantitas, mengurangi pencemaran lingkungan dan meningkatkan kualitas lahan secara berkelanjutan harus mendapat perhatian. Hal itu disebabkan karena sumber bahan untuk pupuk sangat beranekaragam, dengan karakteristik fisik dan kandungan kimia/hara yang sangat beragam sehingga pengaruhnya juga akan bervariasi menurut metode budidaya yang diterapkan seperti SRI dan konvensional.

Pola tanam SRI adalah penambahan pupuk dengan bahan organik sesuai dengan kebutuhan tanaman. Upaya pemupukan dengan bahan organik, merupakan satu tindakan untuk mempertahankan kesuburan dan pro-duktivitas tanah baik secara fisika, kimia maupun biologi tanah.

Pupuk kimia saat ini masih terbatas, sehingga mengakibatkan harganya menjadi mahal dan sebahagian besar petani tidak dapat menjangkau harganya. Ketergantungan terhadap pupuk kimia memang sudah sangat tinggi sesuai dengan apa yang di sampaikan Yuwono, (2005) banyak yang beranggapan semakin banyak pupuk kimia yang digunakan terhadap tanaman maka hasilnya akan semakin banyak. Akibatnya para petani cenderung berlebihan dalam memberikan pupuk kimia sehingga tanah menjadi berubah warna dan keras, kondisi fisik menjadi buruk, hasil panen menurun dari hasil sebelumnya, tanaman menjadi tidak normal pertumbuhannya, meracuni tanah dan mencemari lingkungan, serta berbahaya bagi kesehatan manusia.

Cara untuk mengatasi ketergantungan terhadap pupuk kimia yaitu dengan memberikan bahan organik. Bahan organik cenderung mampu meningkatkan jumlah air yang dapat ditahan di dalam tanah dan jumlah 
air yang tersedia bagi tanaman. Bahan organik juga sebagai sumber energi bagi jasad mikro dan tanpa bahan organik semua kegiatan biokimia akan terhenti. Sejalan dengan apa yang disampaikan Yuwono (2005) berapa pun banyaknya unsur hara yang diberikan kedalam tanah tidak akan pernah menjadikan tanaman menjadi tumbuh subur karena efektifitas penyerapan unsur hara sangat dipengaruhi oleh kadar bahan organik dalam tanah.

Pendapat Barkelaar (2001) kompos dapat dibuat dari bermacam-macam sisa tanaman (seperti jerami, serasah tanaman, dan bahan dari tanaman lainnya). Salah satu bahan organik yang sering diabaikan oleh sebagian besar petani ketika selesai panen adalah jerami padi. Hasil penelitian Mursida (2005) menunjukan bahwa pemberian kompos jerami padi dapat memberikan pengaruh yang lebih baik terhadap pertumbuhan dan hasil tanaman cabai. Menurut Arifin et al. (1993), pemberian 5,0 ton/ha jerami dapat menghemat pemakaian pupuk $\mathrm{KCl}$ sebesar $100 \mathrm{~kg} / \mathrm{ha}$ dan penggunaan kompos jerami sebanyak 5 ton/ha selama 4 musim tanam dapat menyumbang hara sebesar $170 \mathrm{~kg} \mathrm{~K}, 160 \mathrm{~kg} \mathrm{Mg}$, dan $200 \mathrm{~kg} \mathrm{Si}$.

Generasi masyarakat milenial masih kurang menyadari akan pentingnya upaya pengelolaan limbah peternakan salah satunya kotoran ayam. Berdasarkan hasil penelitian Ishak,et al(2013) menyatakan bahwa pemberian kotoran ayam dengan dosis 5 ton/ha memberikan pengaruh yang signifikan terhadap pertumbuhan vegetatif tinggi tanaman.

Hasil penelitian menunjukkan bahwa pupuk kompos sampah organik dan pupuk kandang dapat menyediakan separuh kebutuhan hara bagi budidaya padi, sementara sisanya disediakan oleh pupuk kimia. Temuan ini selaras dengan penelitian lain yang menyatakan bahwa penggunaan pupuk organik dapat mengurangi dosis penggunaan pupuk kimia hingga 50\% yang dilakukan pada satu kali musim tanam padi saja (Sulistyawati dan Nugraha, 2010).
Sumber bahan organik lainnya adalah tithonia. Hasil penelitian Rahayu (2007) menyatakan bahwa pemberian 5 ton/ha kompos tithonia dapat meningkatkan pertumbuhan dan hasil tanaman jagung manis. Pupuk kimia tidak dapat menggantikan fungsi bahan organik karena masing-masing memiliki peranan yang berbeda di dalam tanah. Apabila bahan organik diberikan dengan berkelanjutan maka akan dengan cepat memulihkan kondisi tanah yang ksesuburannya hilang akibat penggunaan bahan kimia pertanian. Penelitian ini bertujuan untuk mengetahui jenis bahan organik yang berpengaruh lebih baik terhadap pertumbuhan dan hasil tanaman padi metode SRI.

\section{METODE PENELITIAN}

Bahan yang digunakan dalam percobaan ini antara lain padi varietas IR 42, kompos sampah kota diperoleh dari TPA (Tempat Pembuangan Akhir) sampah kota , kompos jerami padi, kompos tithonia, kotoran ayam, abu sekam, minyak tanah. Alat yang digunakan adalah bajak, garu, cangkul, sabit, parang, seed bed, meteran, ember, karung goni, karung plastik, alat tulis, ajir dan label.

Rancangan yang digunakan dalam percobaan ini adalah Rancangan Acak Lengkap (RAL) dengan 4 perlakuan dan 3 ulangan, sehingga seluruh percobaan terdiri dari 12 plot kemudian masing-masing plot terdiri dari 64 tanaman dengan total 786 tanaman. Dari masing-masing plot percobaan diambil secara acak 10 rumpun tanaman sampel. Dosis masing-masing bahan organik yang diberikan yang diberikan adalah 5 ton/ha. Data hasil pengamatan dianalisis secara sidik ragam dengan uji $\mathrm{F}$. Kemudian jika $\mathrm{F}$ hitung perlakuan lebih besar dari $\mathrm{F}$ tabel 5\% dilanjutkan dengan Duncan's New Multiple Range Test (DNMRT) pada taraf 5\%. Pengamatan data periodik ditampilkan dalam bentuk grafik. Perlakuan yang digunakan adalah beberapa jenis/sumber bahan organik 
antara lain, sampah kota, kotoran ayam, tithonia, jerami padi.

\section{HASIL DAN PEMBAHASAN}

\section{Tinggi tanaman (cm)}

Pemberian beberapa jenis bahan organik memberikan pengaruh yang berbeda tidak nyata terhadap tinggi tanaman. Rata-rata tinggi tanaman padi pada pemberian beberapa jenis bahan organik ditampilkan pada tabel 1 .

Tabel 1 Tinggi tanaman padi metode SRI pada pemberian beberapa jenis bahan organik.

\begin{tabular}{lc}
\hline $\begin{array}{c}\text { Jenis bahan } \\
\text { organik }\end{array}$ & Tinggi tanaman (cm) \\
\hline Sampah kota & 92.51 \\
Kotoran ayam & 95.19 \\
Thitonia & 93.20 \\
Jerami padi & 92.77 \\
\hline KK $=4,33 \%$ & \\
\hline
\end{tabular}

Angka - angka pada kolom yang sama berbeda tidak nyata menurut uji $\mathrm{F}$ pada taraf nyata $5 \%$.

Pada Tabel 1 terlihat bahwa pemberian bahan organik sampah kota, kotoran ayam, thitonia, dan jerami padi memberikan pengaruh yang sama terhadap tinggi tanaman. Hal ini diduga karena komposisi hara N, P dan $\mathrm{K}$ yang dikandung dari beberapa jenis bahan organik tersebut tidak jauh berbeda, misalnya unsur hara N. Kandungan hara N sampah kota sekitar $32 \mathrm{~kg}$, kotoran ayam sekitar $50 \mathrm{~kg}$, thitonia sekitar $177 \mathrm{~kg}$ dan jerami padi $40 \mathrm{~kg}$ yang dikonversikan kedalam 5 ton/ha. Berdasarkan hasil penelitian IshaK et al. (2013) dengan pemberian pupuk organik kotoran ayam dengan dosis 5 ton/ha sudah memberikan pengaruh yang nyata terhadap pertumbuhan vegetatif tinggi tanaman.

Perbedaan tersebut belum menunjukkan pengaruh yang berbeda terhadap tinggi tanaman karena bahan organik tersebut baru bisa diserap sekitar $30 \%$ karena ketersediannya yang lambat. Alasan ini sejalan dengan pendapat Hakim et al. (1986), bahwa pupuk alam dibandingkan dengan pupuk buatan lebih lambat tersedia serta lambat pula menyediakan unsur nitrogen bagi tanaman, karna harus mengalami perubahan terlebih dahulu. Jika kita lihat menurut rekomendasi untuk $\mathrm{N}$ yang diberikan pada tanaman padi sekitar $200 \mathrm{~kg} / \mathrm{ha}$ sedangkan pada masing- masing bahan organik masih belum memenuhi kebutuhan untuk tanaman sehingga belum bisa memberikan pengaruh yang signifikan. Kemudian berdasarkan deskripsi tanaman padi varietas IR 42 ke -4 bahan organik tersebut belum memberikan pengaruh yang signifikan terhadap tinggi tanaman karena belum melebihi dari deskripsi tanaman.

Sarief (1986) menyatakan bahwa unsur hara $\mathrm{N}$ berfungsi untuk merangsang pertumbuhan vegetatif tanaman seperti batang, daun dan akar serta pembentukan tunas yang memegang peranan penting dalam mendorong dan mempercepat tumbuh atau menambah tinggi tanaman.

Alasan yang telah diungkapkan diatas selanjutnya diperkuat pula dengan laju pertumbuhan tinggi tanaman dari umur 2 minggu setelah tanam (MST) sampai umur 9 minggu setelah tanam (MST) seperti yang telah tersaji pada gambar 1 . 


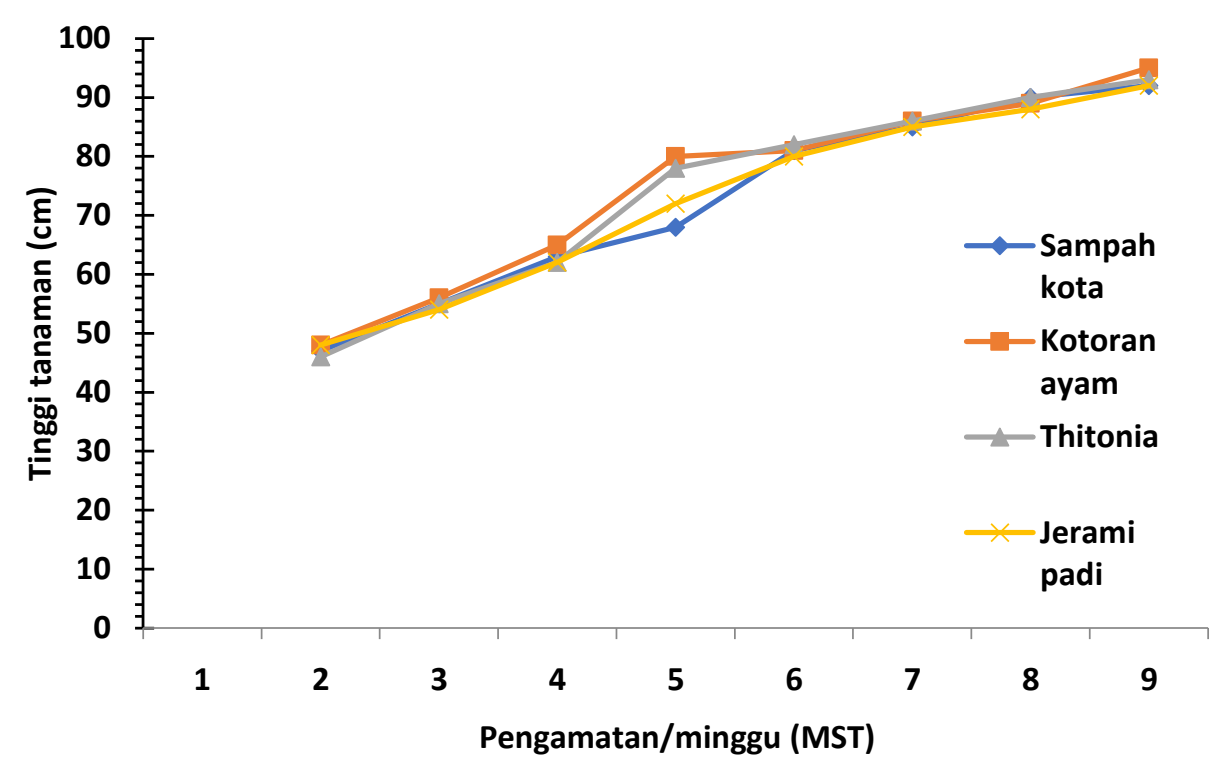

Gambar 1 Grafik laju pertumbuhan tinggi tanaman pada metode SRI dari umur 2 mst sampai 9 MST

Pada gambar 1 terlihat bahwa laju pertumbuhan tinggi tanaman mulai dari 2 minggu setelah tanam (MST) sampai 9 minggu setelah tanam (MST) terlihat hampir sama, yaitu sekitar $7 \mathrm{~cm}$, kecuali pada minggu ke 5 setelah tanam. Pada minggu ke 5 setelah tanam pemberian bahan organik kotoran ayam lebih tinggi dibandingkan bahan organik lainnya. Hal ini diduga sebagai akibat perbedaan $\mathrm{N}$ yang disumbangkan kotoran ayam lebih tinggi dari bahan organik lainnya pada minggu ke 5 setelah tanam itu saja. Namun perbedaan itu tidak lagi menyebabkan perbedaan laju pertumbuhan pada minggu berikutnya sampai minggu ke 9 setelah tanam.

\section{Jumlah anakan/rumpun (batang)}

Pemberian beberapa jenis bahan organik memberikan pengaruh yang berbeda nyata terhadap jumlah anakan/rumpun pada tanaman padi minggu ke 8 dan pemberian beberapa jenis bahan organik memberikan pengaruh yang berbeda tidak nyata terhadap jumlah anakan/rumpun pada tanaman padi pada minggu ke 9 setelah tanam. Rata-rata jumlah anakan/rumpun minggu ke 8 dan 9 ditampilkan pada tabel 2.

Tabel 2 Jumlah anakan / rumpun tanaman padi metode SRI pada pemberian beberapa jenis bahan organik umur 8 dan 9 minggu setelah tanam (MST)

\begin{tabular}{|c|c|c|}
\hline Jenis bahan organik & $\begin{array}{c}\text { Jumlah Anakan/Rumpun } \\
\text { minggu ke } 8 \text { (Batang) }\end{array}$ & $\begin{array}{l}\text { Jumlah Anakan/ } \\
\text { Rumpun minggu } \\
\text { ke } 9 \text { (Batang) }\end{array}$ \\
\hline Sampah kota & $33.4 \mathrm{a}$ & 37.47 \\
\hline Kotoran ayam & $41.5 \quad b$ & 35.25 \\
\hline Thitonia & $45.6 \quad b$ & 37.33 \\
\hline
\end{tabular}




\begin{tabular}{ccc}
\hline Jerami padi & 35.8 a & 31.33 \\
\hline & $\mathrm{KK}=42.32 \%$ & $\mathrm{KK}=14,59 \%$ \\
\hline
\end{tabular}

Angka-angka pada lajur yang sama yang diikuti huruf kecil yang sama berbeda tidak nyata menurut DNMRT pada taraf nyata 5\%

Pada tabel 2 ada dua jenis data yang disajikan terhadap jumlah anakan/rumpun yaitu umur tanaman padi pada minggu ke 8 dan minggu ke 9 setelah tanam. Pada minggu ke 8 dapat dilihat bahwa jumlah anakan paling tinggi terlihat pada pemberian bahan organik thitonia. Hal ini diduga sebagi akibat dari perbedaan kandungan komposisi hara N, P dan $\mathrm{K}$ yang terkandung dalam thitonia berbeda dengan bahan organik lainnya yaitu sampah kota, jerami padi dan kotoran ayam. Bahan organik thitonia tersebut misalnya $\mathrm{N}$ lebih besar kandungannya dibandingkan bahan organik lainnya. Dengan melihat tabel 2 pada minggu ke 8 setelah tanam pengaruh yang paling baik terdapat pada pemberian bahan organik thitonia terhadap jumlah anakan/rumpun.

Pada fase vegetatif memasuki minggu ke 7 sampai minggu ke 8 setelah tanam jumlah anakan sudah terlihat gejala serangan terhadap anakan tanaman padi tetapi belum memperlihatkan kerusakan yang signifikan dan jumlah anakan masih terlihat seperti pada minggu sebelumnya. Pengendalian yang dilaksanakan yaitu dengan memberikan abu sekam yang dicampur dengan minyak tanah kemudian disiramkan pada bagian pangkal tanaman padi karena hama penggerek tersebut menyerang pada pangkal batang, tujuannya agar bisa menekan kehilangan jumlah anakan karena anakan merupakan salah satu komponen hasil yang dapat mempengaruhi hasil tanaman secara keseluruhan. Kemudian ketika memasuki minggu ke 9 pada akhir pengamatan vegetatif ternyata pengendalian yang dilaksanakan masih belum maksimal buktinya anakan yang dihasilkan berkurang pada akhir pengamatan vegetatif. Hama penggerek yang menyerang fase vegetatif dapat menghambat titik tumbuh atau bahkan mematikan titik tumbuh anakan padi. Serangan hama penggerek batang padi tersebut dapat mengurangi jumlah anakan/rumpun sehingga mempengaruhi data pada akhir pengamatan seperti yang telah disajikan pada tabel 2 minggu ke 9 setelah tanam.

Salah satu unsur hara yang mempengaruhi jumlah anakan adalah unsur $P$. Harran (1975) menyatakan bahwa Unsur phospor yang diserap tanaman berperan dalam aktivitas pembelahan sel. Pembentukan sel akan membantu pembentukan anakan padi, maka dengan semakin meningkatnya penyerapan $\mathrm{P}$ oleh tanaman akan meningkatkan jumlah anakan padi. Dalam hal ini $\mathrm{P}$ yang diserap oleh tanaman padi yang disumbangkan oleh masing-masing bahan organik sama saja pengaruhnya pada pembentukan jumlah anakan/rumpun tanaman padi.

Deptan Badan Pengendali Bimas Jakarta (1977) menyatakan bahwa Jumlah anakan maksimum biasanya dicapai pada minggu ke enam atau ke tujuh setelah tanam. Jumlah anakan maksimum/rumpun dapat digolongkan : sangat rendah ( $<5$ batang), rendah (5-8 batang), sedang (9-12 batang), tinggi (13-16 batang) dan sangat tinggi (>16 batang). Untuk varietas yang ditanam yaitu IR 42 termasuk kedalam kategori sangat tinggi karena lebih dari 16 batang dan biasanya dengan SRI bisa mencapai > 50 sementara pada Tabel 2 belum memperlihatkan secara SRI seperti yang diharapkan. Alasan yang telah diuraikan diatas selanjutnya diperkuat pula dengan laju pertumbuhan jumlah anakan/rumpun dari umur 2 sampai 9 setelah tanam seperti yang telah tersaji pada gambar 2. 


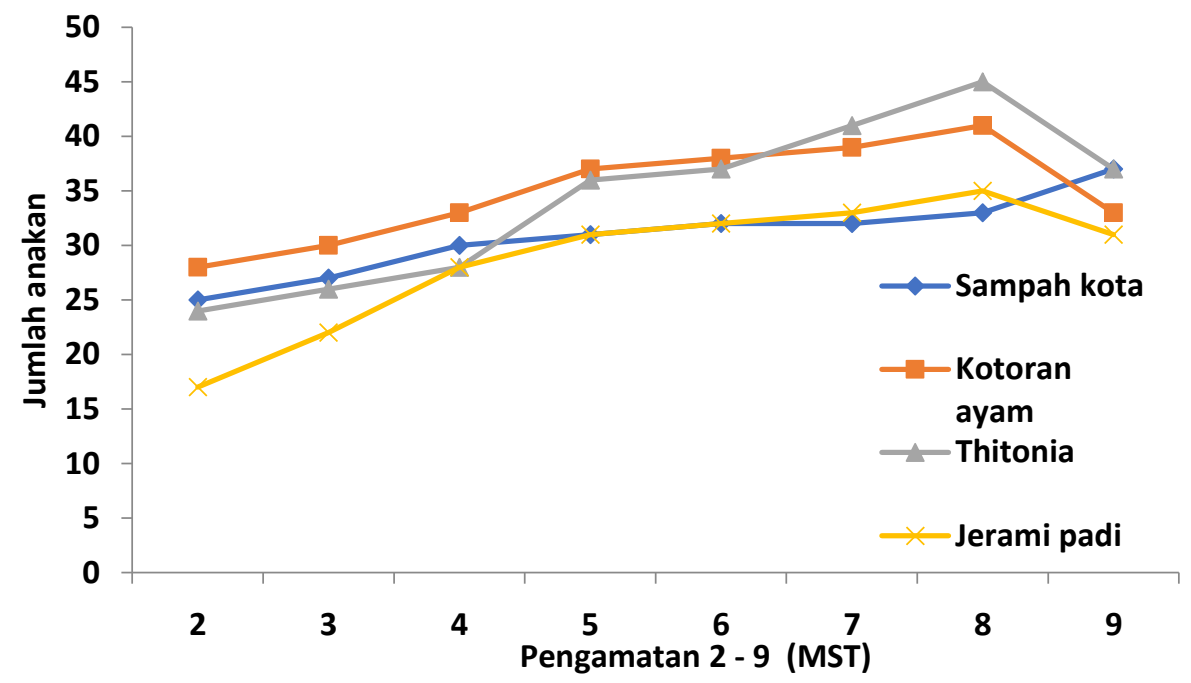

Gambar 2 Grafik laju pertumbuhan jumlah anakan/rumpun pada metode SRI dari umur 2 (MST) sampai 8 (MST)

Pada gambar 2 terlihat bahwa laju pertumbuhan jumlah anakan mulai dari minggu ke 2 setelah tanam sampai minggu ke 7 setelah tanam hampir sama yaitu 3 - 4 batang setiap minggunya kecuali pada minggu ke 8 setelah tanam. Pada minggu ke - 8 setelah tanam pemberian bahan organik thitonia lebih tinggi dibandingkan bahan organik lainnya. Hal ini diduga hara yang disumbangkan thitonia lebih tinggi dibandingkan bahan organik lainnya. Namun pada minggu ke 9 jumlah anakan mengalami penurunan. Hal ini disebabkan karena faktor lingkungan biotik yaitu hama penggerek batang padi. Hama penggerek batang padi tersebut menyerang fase vegetatif yang mengakibatkan titik tumbuh tanaman padi terhambat bahkan mati sehingga mengurangi jumlah anakan, kecuali pada bahan organik sampah kota, jumlah anakan pada sampah kota tidak terlihat penurunan secara drastis tetapi sebenarnya pada bagian ini terjadi serangan hama penggerek hanya saja serangan tersebut tidak memperlihatkan penurunan jumlah anakan yang signifikan jika dibandingkan dengan bahan organik lainnya. Hal ini diduga karena bahan organik kotoran ayam, thitonia dan jerami padi lebih disukai oleh hama penggerek tersebut dan jika dilihat kandungan hara misalnya $\mathrm{N}$ pada ke tiga jenis bahan organik lebih tinggi dibandingkan sampah kota sehingga meyebabkan supulen yang menyebabkan patogen berkembang. Jika kandungan $\mathrm{N}$ tinggi maka tanaman akan menjadi lunak dan akan rentan terhadap hama dan penyakit. Faktor lain yang diduga karena iklim mikro yang berada pada bahan organik lain seperti kotoran ayam, thitonia dan jerami padi lebih disukai hama penggerek batang padi sehingga mendukung untuk melanjutkan siklus hidup hama tersebut.

Serangan hama penggerek batang tersebut mengakibatkan jumlah anakan berkurang sehingga mempengaruhi data akhir pengamatan seperti yang telah tersaji pada Tabel 2. Hama yang menyerang tanaman padi umur 45 hari setelah tanam (HST), hama tersebut berada pada pangkal batang dan gejala yang ditimbulkannya tanaman padi menjadi kuning pada masa vegetatif dan mematikan titik tumbuh yang menyebabkan anakan mati dan berkurang sehingga mempengaruhi data akhir seperti yang telah disajikan pada Tabel 2 minggu ke 9 setelah tanam.

Serangan baru terlihat pada saat tanaman berumur delapan minggu setelah tanam. Serangan diakibatkan oleh hama penggerek batang padi yang masih dalam stadia larva. Larva ini diduga terbawa melalui aliran air yang berasal dari petakan 
sawah milik petani. Menurut Suharto (2007), sebagian larva mengapung di air pada potongan daun. Larva yang jatuh ke dalam air akan berenang menuju tanaman lain. Larva yang baru menetas akan menuju batang padi dan memakan tangkai atau pangkal daun pucuk. Apabila batang padi dibelah maka akan terlihat larva di dalamnya.

Berdasarkan hasil penelitian Tufalia et al. (2014) menyatan bahwa untuk pertumbuhan vegetatif dengan pemberian pupuk organik kotoran ayam dengan dosis 5 ton/ha sudah mampu memberikan petumbuhan yang signifikan tanaman mentimun dengan ditandai oleh perbaikan kimia tanah. Jika pertumbuhan vegetatif bagus diharapakan pertumbuhan generatifnya juga akan bagus

\section{Jumlah anakan produktif (batang)}

Pada pembahasan sebelumnya pemberian bahan organik sampah kota, kotoran ayam, thitonia dan jerami padi memberikan pengaruh yang sama terhadap jumlah anakan/rumpun maka jumlah anakan produktif akan memberikan pengaruh yang sama juga karena jumlah anakan produktif tidak terlepas dari jumlah anakan/rumpun. Jumlah anakan produktif/rumpun berasal dari jumlah anakan/rumpun. Berdasarkan deskripsi padi varietas IR 42 jumlah anakan produktif yang dihasilkan sekitar $20-25$ batang walaupun sudah terpenuhi tetapi bahan organik tersebut memberikan pengaruh yang sama pada jumlah anakan produktif atau belum menunjukkan perbedaan yang signifikan.

Tabel 3 Jumlah anakan produktif/rumpun tanaman padi metode SRI pada pemberian beberapa jenis bahan organik

\begin{tabular}{lc}
\hline \multicolumn{1}{c}{$\begin{array}{c}\text { Jenis bahan } \\
\text { organik }\end{array}$} & $\begin{array}{c}\text { Tinggi } \\
\text { tanaman }(\mathbf{c m})\end{array}$ \\
\hline Sampah kota & 24,14 \\
Kotoran ayam & 27,05 \\
Thitonia & 28,01
\end{tabular}

Jerami padi

22,68

$\mathrm{KK}=16,73 \%$

Angka - angka pada kolom yang sama berbeda tidak nyata menurut uji $\mathrm{F}$ pada taraf nyata $5 \%$.

Pada tabel 3 terlihat bahwa pemberian beberapa jenis bahan organik memberikan pengaruh yang berbeda tidak nyata terhadap jumlah anakan produktif tanaman padi metode SRI. Hal ini sebagai akibat dari hasil jumlah anakan/rumpun yang disajikan pada Tabel 2 di atas. Menurut Soemartono et al (1984), jumlah anakan produktif ditentukan oleh jumlah anakan maksimum. Jumlah anakan produktif per rumpun tampak berkurang jika dibandingkan jumlah anakan total per rumpun. Hasil penelitian Putri, (2015) kompos jerami padi dengan dosis 5 ton/ha sudah memberikan pengaruh yang signifikan terhadap jumlah anakan produktif. Menurut Suseno (1975) cit Wardhana (2006) anakan yang tidak produktif akan mati karena persaingan zat makanan yang ketat, dan jumlah anakan akan tetap sampai stadia bunting.

\section{Persentase anakan produktif ( \%)}

Hasil analisis ragam menunjukkan bahwa persentase anakan produktif memberikan pengaruh yang berbeda tidak nyata pada pemberian beberapa jenis bahan organik terhadap tanaman padi dengan metode SRI. Pada tabel 4 disajikan rata-rata persentase jumlah anakan produktif metode SRI pada pemberian beberapa jenis bahan organik.

Tabel 4 Persentase anakan produktif/rumpun tanaman padi metode SRI pada pemberian beberapa jenis bahan organik

\begin{tabular}{lc}
\hline $\begin{array}{c}\text { Jenis bahan } \\
\text { organik }\end{array}$ & $\begin{array}{c}\text { Tinggi tanaman } \\
(\mathbf{c m})\end{array}$ \\
\hline Sampah kota & 66,71 \\
Kotoran ayam & 77,62 \\
Thitonia & 75,59 \\
Jerami padi & 71,55 \\
\hline KK $=16,61 \%$ & \\
\hline
\end{tabular}


Angka - angka pada kolom yang sama berbeda tidak nyata menurut uji $\mathrm{F}$ pada taraf nyata $5 \%$.

Pada tabel 4 ditunjukkan bahwa pemberian beberapa jenis bahan organik memberikan pengaruh yang berbeda tidak nyata terhadap tanaman padi dengan metode SRI dengan kata lain bahan organik sampah kota, kotoran ayam, thitonia dan jerami padi memberikan pengaruh yang sama terhadap persentase anakan produktif. Hal ini merupakan sebagai akibat dari jumlah anakan/rumpun dan jumlah anakan produktif/rumpun. Karena persentase anakan produktif dihitung berdasarkan anakan produktif dan jumlah anakan yang telah tersaji pada tabel 2 dan Tabel 3. Secara keseluruhan peranan dari $\mathrm{N}, \mathrm{P}$ dan $\mathrm{K}$ memberikan pengaruh yang sama terhadap pertumbuhan vegetatif pada pemberian bahan oganik sampah kota, kotoran ayam, thitonia dan jerami padi karena pada dasarnya ketiga unsur ini saling berinteraksi dalam pertumbuhan tanaman.

\section{Panjang malai}

Hasil analisis ragam terhadap pengamatan panjang malai tanaman padi metode SRI pada pemberian beberapa jenis bahan organik menunjukkan pengaruh yang berbeda tidak nyata. Pada Tabel 5 disajikan rata-rata dari panjang malai.

Tabel 5 Panjang malai tanaman padi metode SRI pada pemberian beberapa jenis bahan organik

\begin{tabular}{lc}
\hline Jenis bahan organik & $\begin{array}{c}\text { Panjang } \\
\text { Malai }(\mathbf{c m})\end{array}$ \\
\hline Sampah kota & 25,12 \\
Kotoran ayam & 25,65 \\
Thitonia & 25,93 \\
Jerami Padi & 25,47 \\
\hline
\end{tabular}

$\mathrm{KK}=1,60 \%$

Angka-angka pada lajur yang sama berbeda tidak nyata menurut uji $\mathrm{F}$ pada taraf nyata $5 \%$

Pada tabel 5 pemberian bahan organik sampah kota, kotoran ayam, thitonia dan sampah kota memberikan pengaruh yang sama terhadap panjang malai. Pada pembahasan sebelumnya, tinggi tanaman, jumlah anakan, jumlah anakan produktif dan persentase anakan produktif memberikan pengaruh yang sama. Keempat pengamatan tersebut adalah fase vegetatif. Fase vegetatif akan memberikan pengaruh terhadap fase generatif, karena jika fase vegetatif pertumbuhannya baik akan memberikan pengaruh yang baik juga terhadap fase pertumbuhan generatif.

Pemberian nitrogen akan mempengaruhi jumlah anakan yang selanjutnya juga meningkatkan jumlah dan panjang malai. Panjang malai tanaman padi tidak hanya dipengaruhi oleh faktor internal dari tanaman padi, sehubungan dengan ini unsur yang paling berpengaruh terhadap pan $\neg$ jang malai adalah unsur nitrogen. Jika dilihat dari kandungan $\mathrm{N}$ pada masing-masing bahan organik komposisi kandungannya relatif sama sehingga panjang malai juga memberikan pengaruh yang sama.

Setyono dan Suparyono (1993) menyatakan bahwa panjang malai tergantung pada varietas padi yang ditanam. Ukuran panjang malai dibedakan menjadi tiga ukuran, yaitu (a) malai pendek yang berukuran $<20 \mathrm{~cm}$, (b) malai sedang yang berukuran antara $20-30 \mathrm{~cm}$, (c) malai panjang yang berukuran $>30 \mathrm{~cm}$. Jadi, panjang malai varietas padi IR 42 yang digunakan termasuk kategori sedang yaitu berukuran sekitar $25 \mathrm{~cm}$.

\section{KESIMPULAN}

Dari hasil penelitian dapat diambil kesimpulan bahwa pemberian beberapa jenis bahan organik jenis sampah kota, kotoran ayam, thitonia dan jerami padi memberikan pengaruh yang sama terhadap tanaman padi Metode SRI, kecuali jumlah anakan minggu ke 8 setelah tanam. Pengaruh yang paling baik terhadap jumlah anakan pada minggu ke 8 setelah tanam adalah thitonia dibandingkan 
kotoran ayam, jerami padi dan sampah kota.

\section{DAFTAR PUSTAKA}

Arifin Z. Suprapto, Fagi AM. 1993. Pengaruh Kalium dan Organik Terhadap Hasil Padi Sawah. Reflektor Balittan Sukamandi. 6 (12): 13-17.

Barkelaar D. 2001. EDN Stories: SRI, The System of Rice Intensification: Less Can be More. http:// www.echonet.org. Diakses : 18 November 2009.

Departemen Pertanian Badan Pengendali Bimas. 1977. Pedoman Bercocok Tanam Padi, Palawija dan Sayur sayuran. Jakarta (ID): Departemen Pertanian Badan Pengendali Bimas.

Hakim N, Nyakpa MY, Lubis AM, Nugroho MR, Saul MA, Diha GB Bailey HH. 1986. Dasar-dasar Ilmu Tanah. Padang (ID): Universitas Andalas.

Harran S. 1975. Fisiologi Tanaman Padi. Bogor (ID): Fakultas Pertanian Institut Pertanian Bogor.

Ishak SY, Bahua MI, Limonu M. 2013. Pengaruh Pupuk Organik Kotoran Ayam terhadap Pertumbuhan Tanaman Jagung (Zea mays L.) di Dulomo Utara Kota Gorontalo. Gorontalo JATT. 2 (1): 210-218.

Mursida. 2005. Pengaruh pemberian beberapa dosis kompos jerami padi hasil pelapukan Trichoderma harzianum terhadap pertumbuhan dan hasil tanaman cabai (Capsicum annum). [skripsi]. Padang (ID): Universitas Andalas.

Putri AD. 2015. Pemanfaatan kompos jerami untuk meningkatkan pertumbuhan dan produksi padi Sawah (Oryza sativa L.) di Desa Pematang Setrak, Sumatera Utara. [tugas akhir]. Payakumbuh (ID): Politeknik Negeri Payakumbuh.

Rahayu S. 2007. Pengaruh beberapa takaran kompos titonia terhadap per- tumbuhan dan hasil tanaman jagung manis (Zea mays saccharata Sturt). [skripsi]. Padang (ID): Universitas Andalas.

Sarief ES. 1986. Kesuburan dan Pemupukan Tanah Pertanian. Bandung (ID): Pustaka Buana.

Setyono, Suparyono. 1993. Padi. Jakarta (ID): Penebar Swadaya.

Soemartono, Samad, Hardjono. 1984. Bercocok Tanam Padi. Jkarta (ID): Yasaguna.

Suharto. 2007. Pengenalan dan Pengendalian Hama Tanaman Pangan. Yogyakarta (ID): C.V. Andi.

Sulistyawati E, Nugraha R. 2010. Efektivitas Kompos Sampah Perkotaan Sebagai Pupuk Organik dalam Meningkatkan Produktivitas dan Menurunkan Biaya Produksi Budidaya Padi. https:// www.researchgate.net/publication/2 67947725. Diakses 7 Desember 2016. 22.35.WIB.

Tufaila M, Laksana DD, Alam S. 2014. Aplikasi Kompos Kotoran Ayam Untuk Meningkatkan Hasil Tanaman Mentimun (Cucumis sativus L) di Tanah Masam. Jurnal Agroteknos. 4 (2) : 119-126.

Wardhana B. 2006. Pertumbuhan dan hasil beberapa varietas padi (Oryza sativa L) dengan sistem intensifikasi padi (the system of rice intensification). [skripsi]. Padang (ID): Universitas Andalas.

Yuwono D. 2005. Kompos. Jakarta (ID): Penebar Swadaya. 